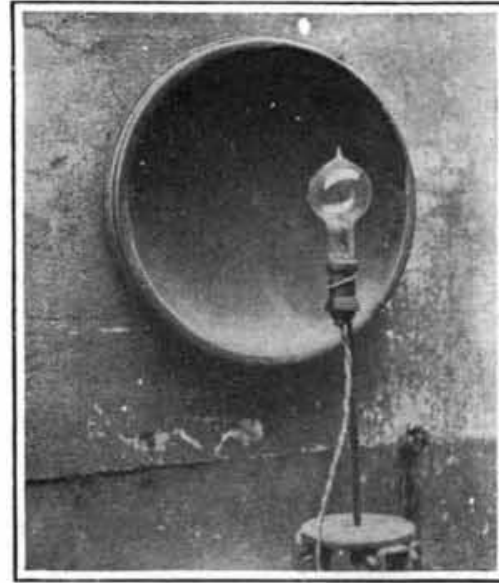

Thermopile mounted in sealed bulb, and parabolic mirror

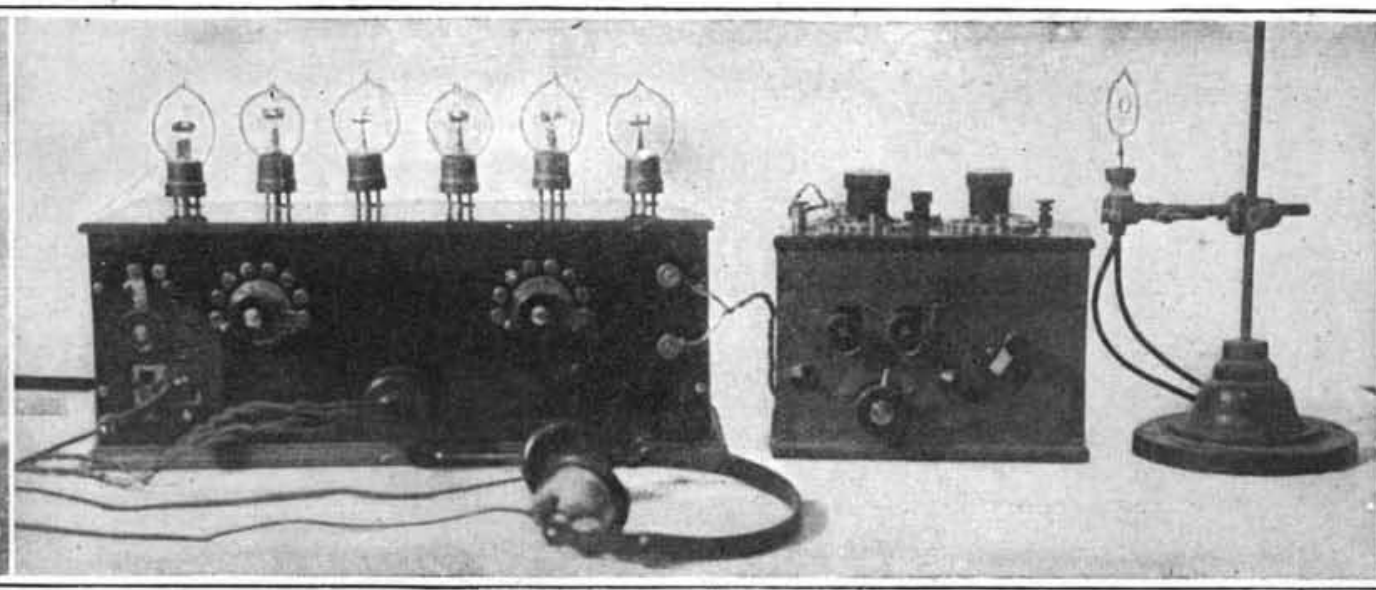

Complete receiver for infra-red rays, consisting of six-stage amplifier, potentiometer and tikker unit,thermopile, and head 'phones

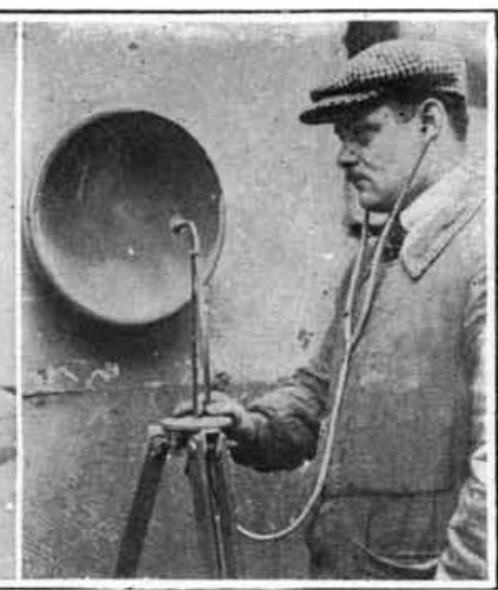

Diminutive horn which produces direct audible signals

\title{
Putting Infra-Red Rays to Work
}

\author{
How the French Army and Navy Make Use of Heat Rays for Invisible Signalling
}

\section{By George Gaulois} A SMALL searchingt provided with a shutter into the dots and dashes of the Morse code; a special screen for that searchlighit which permits only the invisible infra-red rays to pass on; a parabolic mirror several miles away which gathers the infra-red rays from the transmitting searchlight and concentrates them on a special heat-operated detector; a collection of vacuum-tube amplifiers, potentiometers, interrupters and other equipment-all these things blended together in the proper way make a most remarkable system of infra-red ray or invisible light signalling developed by the French during the world war.

Infra-red and ultra-violet rays are commonly termed invisible light, because they are invisible to the human eye although visible to some of the living creatures. Light rays beyond the extreme red of the spectrum are invisible to the human eye because their wave length is greater than those to which the nerves of the human eye are sensitive; or, to state the same thing in another may, because their frequency is too weak to be detected by our organs of vision. So the infra-red rays, wilth which we are very much concerned in the description that follows, are to all intents and purposes invisible and inaudible and hence cannot be detected by the usual means.

The principal physical action produced by infra-red rays is to heat those objects on which they fall. For that reason they are often referred to a s heat rays. These rays can be reflected, refracted, absorbed, polarized and diffracted. And it is precisely these properties that have been taken advantage of in developing the French system of invisible signalling with infra-red rays, under the guidance of J. Herbert-Sitevens and A. Larigalidie of the French Army.

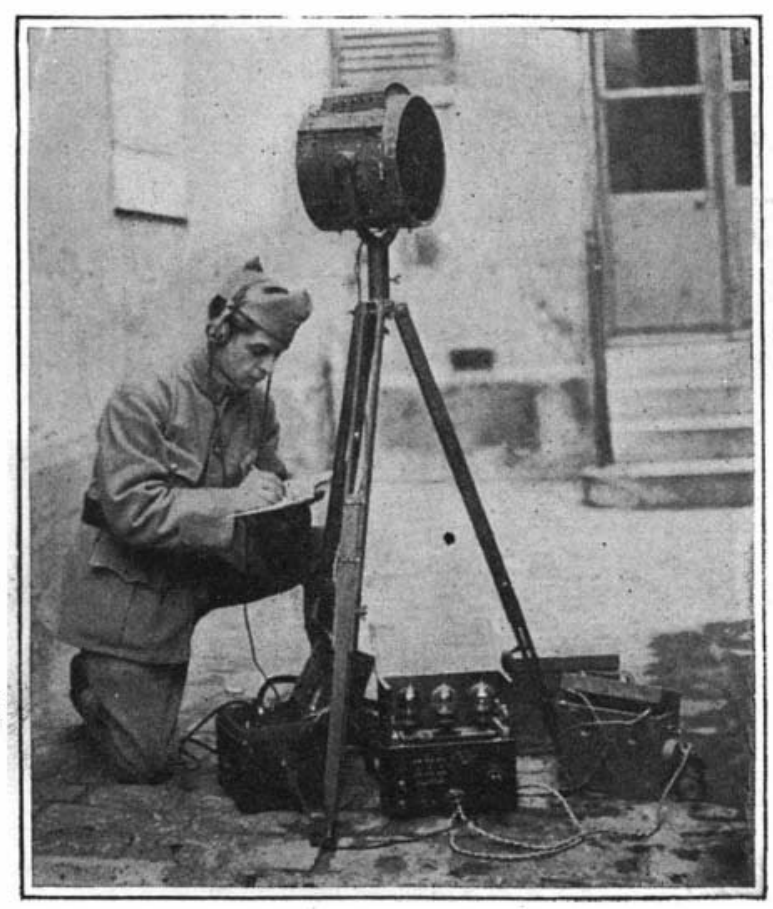

Small portable infra-red transmitter and receiver combined, with three-stage amplifie

The new system of invisible signalling has several advantages over other existing means, just as it has several disadvantages In truth, in military commu- nication it fills a need that has remained untouched despite the heliograph, radio telegraph and telephone, field telegraph, semaphore, wig-rrag, and so on. The infra-red telegraph system requires no connecting wires between the two stations, hence it is ready for instant operation despite its extreme portability; and it is immune to the danger of interruption due to military action. It is a wireless system, so to speak. Most important of all, this system insures absolute secrecy, which cannot be claimed for any other existing method. In militiary use the infra-red telegraph messages cannot be intercepterl by the enemy except by the merest chance, since it is necessary first to locate the invisible beam of light, and then employ suitable apparatus to translate the rays into intelligible signals. And even if the enemy did intercept the bearm, the fact immediately becomes known to the operaltors, and the beam can be shifted to a predetermined point so as to baffle the eavesdrapper.

The transmitting end of this system consists of a source of light which is rich in infra-red radiation. A parabolice refleotor concentrates both the visible and the invisible rays into a thin pencil of light which is projected in the direction of the receiving station However, before permitting the light mays to leave the projector, they are passed through a special screen or ray filter which absorbs all the visible rays and passes only the infra-red or invisible rays. This screen consists of black manganese-dioxide glass or a colored gelatine or cellophane.

As for the actual generation of the infra-red rays, the electric arc is preferred to all other forms of illumimants because of its great volume of lighit. Messis. Herbert-Stevens and Larigaldie have made numerous Continued on page 260 )

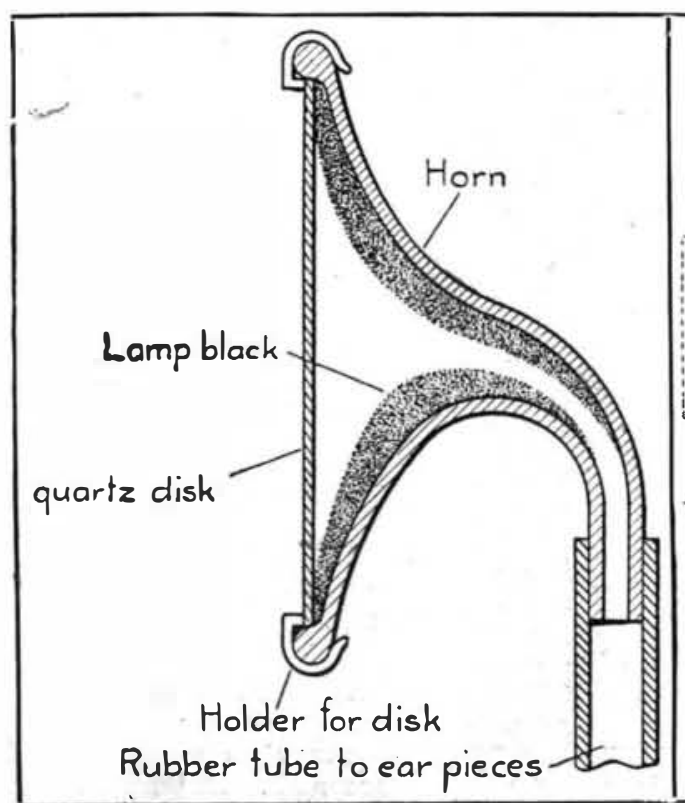

Cross-sectional view of the diminutive horn device

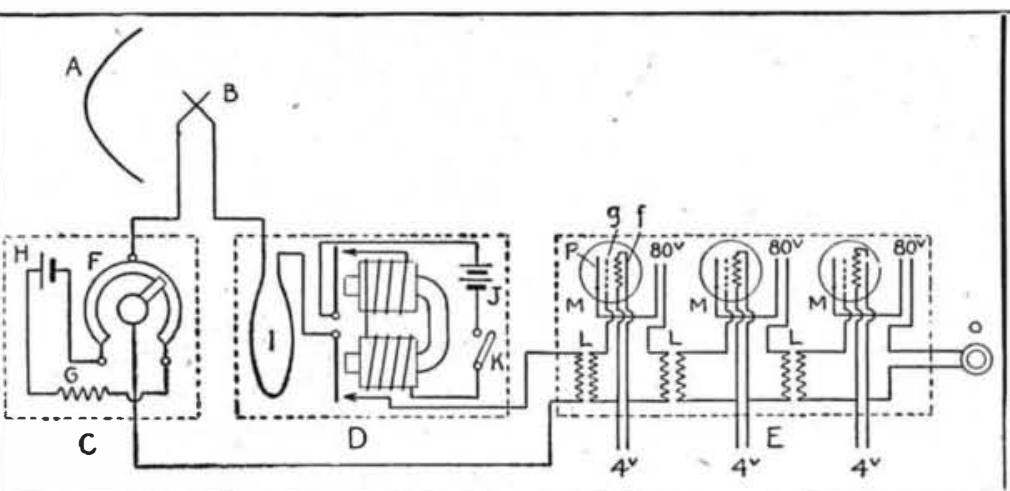

In the above diagram: A. Parabolic reflector. B. Thermopile. C. Potentiometer. $D$. Tikker. $E$. Amplifler. $F$. Resistance of 4 ohms. G. Resistance of 10,000 ohms. H. Two-volt battery. I. Conducting cord. $J$. Tikker battery. $\quad K$. Switch for tikker. L. Transformers ior amplifler circuits. M. Vacuum tubes. $O$. Telephones. At the right: M. Parabolic mirror. C. Thermopile. P. Potentiometer. T. Tikker. F. Fourohm resistance. $R$. 20.000-0hm resistance. $P$. Batteries.

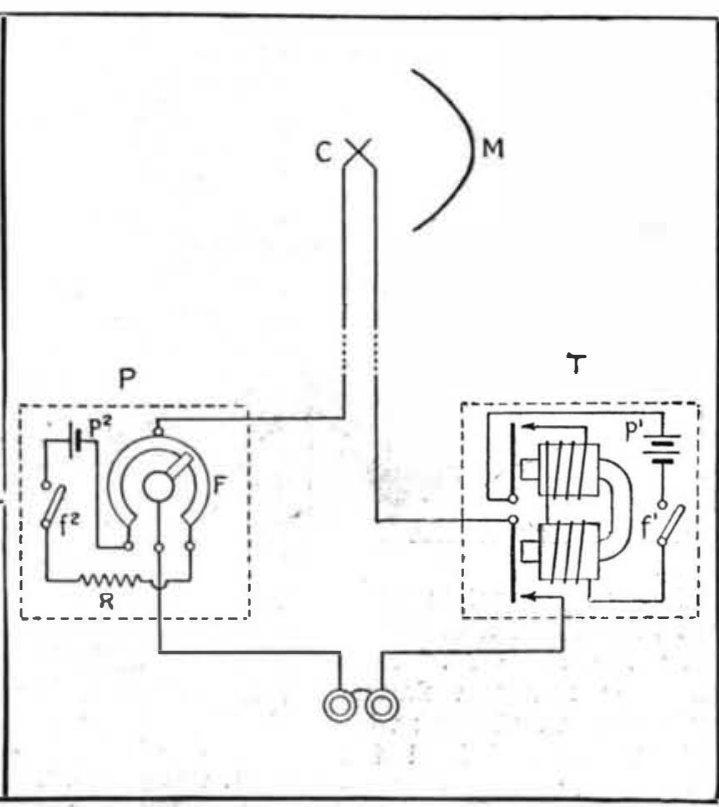

Wiring diagram for an infra-red receiving station complete with three-stage amplifier
Si mple receiver in which there is no anghification 


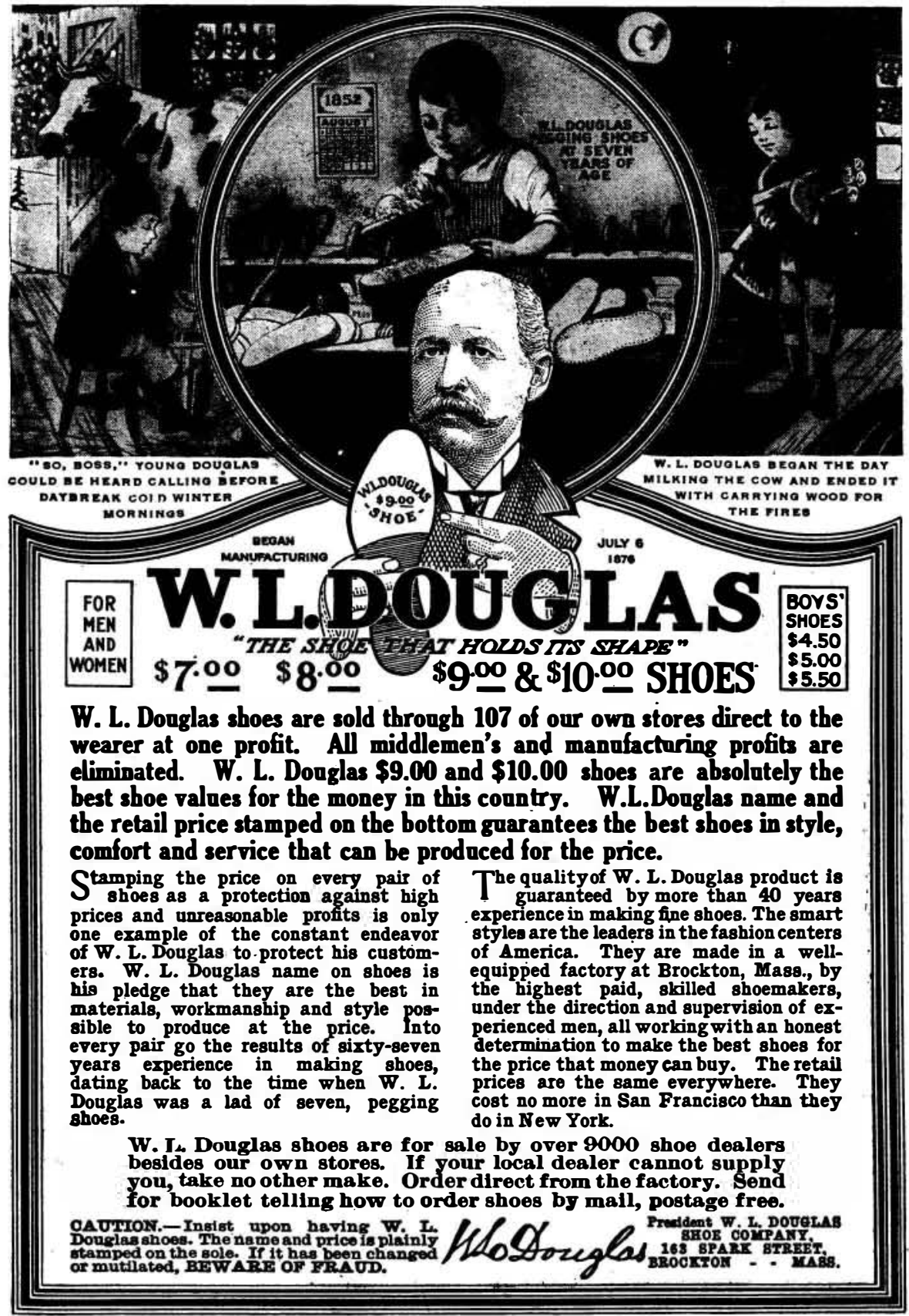

\section{The Design and Construction of Induction Coils} 63/4993/4 inches. Cloth. 272 pages. 159 illustrations. $\$ 3.50$; by mail, $\$ 3.65$

This work gives in minute details full practical directions for making eight different sizes of coils varying from a small one giving a $1 /$-inch spark to a large one giving 12 -inch sparks. The dimensions
of each and every part are given and the description are written in language easy comprehended. Scientific AMERICAN PUBLISBing Co., Woolworth Building, New York City

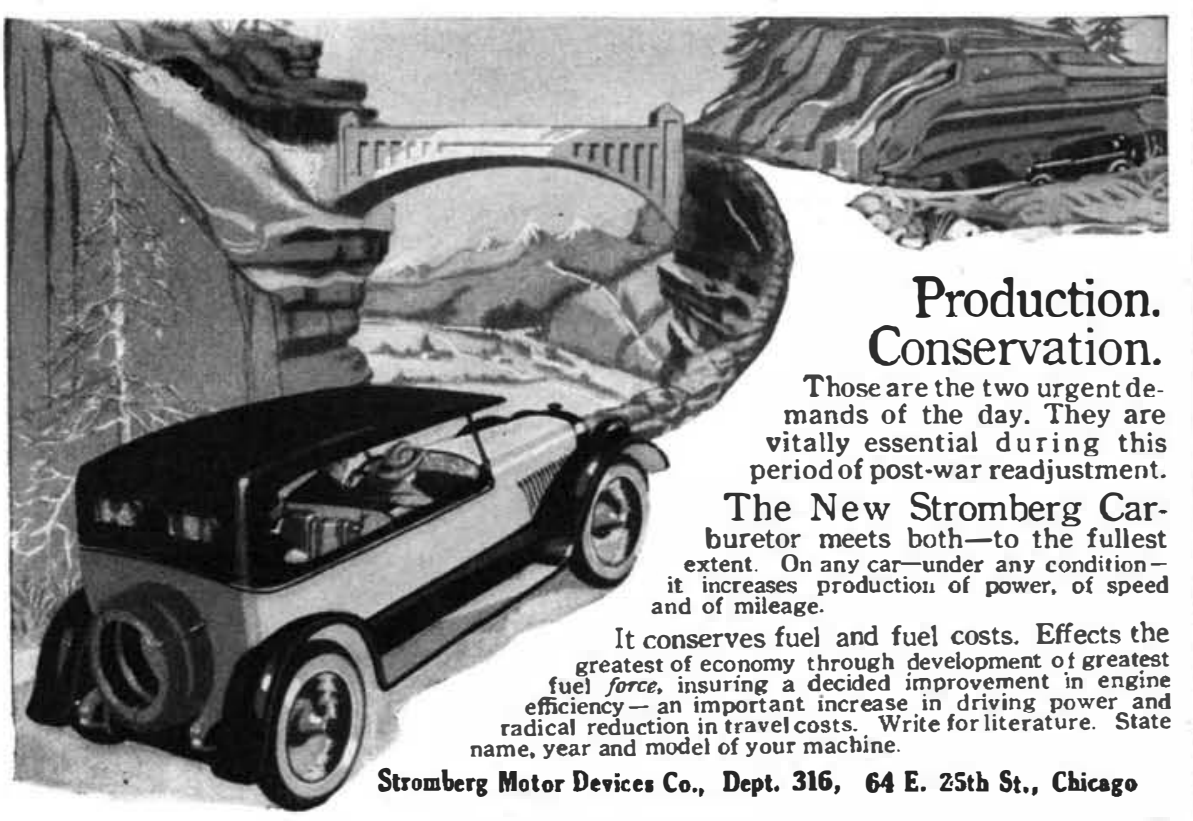

\section{New STRAomigapg Does in!}

Wreck-Proof Safe for OceanGoing Mail

(Continued from page 258)

it floats better in this form. The safes float on the bulkhead principal and the
greatest care is taken in their manufacture to prevent any passible leakage of sea water. They are made without riveting and all joints are welded and hammered. In case of fire on board ship the safes are made to withstand a tremendous heat without melting or injury to the contents. They are really constructed of three different sheets of specially made steel, each built inside the other, giving the safes greater buoyancy and security. When a shipwreck occurs and a safe with its precious contents is cast adrift on a stormy sea, it is by no means a deck of each safe is a complete signal apparatus, which when the safe is thrown overboard and cast adrift from its cradle gets to work automatically onehalf hour after the safe fioats, showing a bright light every fourth minute for
one minute just like a miniature lighthouse. But this is not all, as every ninth minute a signal horn sounds for one minute. These operations will keep up during three months, should the safe remain afloat that long without being found, while in addition to them for twelve hours after the safe leaves

rocket is set off every hour.

After the postal authorities at a Dutch port have put the mail in a safe it is closed with two or more covers provided with special locks and keys. But the safety of the contents does not end here, as should the safe be cast afioat a device fastens the innnerinost cover so that it can only te opened by using a postal se with one separate compartment which auwith one separate compartment which au-
tomatically destroys all its contents should an unauthorized person attempt to open the safe. In other words the safe is as nearly a human guardian as it is possible to make an inanimate object. the use of the foating safes special stamps have been issued by the Dutch Government. These stamps are now on sale at postoffices all over Holland, and one of them attached to a letter or package entitles it to be placed in the safe during the sea voyage.

The captain on board every ship carrying a mail safe is provided with keys to the safe and during the voyage should any of the passengers desire to place mails or valuables in the safe, they can do so by paying a small fee. All such parcels
must also bear the special stamps to be purchased on boand ship, and the address where the valuable are to be sent when the safe is found and opened in case of shipwreck.

\section{How the Chinese Make Their Beautiful Enamel-work Continued from page 247)}

takes fine strips of copper, each strip being about a sixteenth of an inch wide and about the thickness of stout paper These he glues edgewise upon the black outlines of the pattern on the bronze
vessel. The wire must follow the design vessel. The wire must follow the design detail, each curve being perfect, and each angle sharp. Infinite patience and skill are required, for it often takes months to execute an intricate design. The glue used to attach the wires to the vessel is prepared from the roots of orchids.

When the wirework is completed the whole pattern has been outlined in strips of fine copper, which form the cells, or cloisons, in which the pigments are afterwards placed. It is from the cloisons that the work takes its name-cloisonnéwork.

Having got the wires attached, the next thing is to cover the whole surface with a kind of solder. To do this the enameller carefully brushes the vessel over with borax. He places an iron ferrule around the top and bottom rims to prevent warp ing, encloses the whole in an iron wire age and packs it around with charcoal. Then he fires it for about fifteen minutes, controlling the heat by the skillful use of a fan, which he holds in his hand. At the end of the firing the mixture on the outside has fused and the surface has been coated all over, perfectly, with the silver alloy.

The artisan now brushes the surface with an acid preparation made from apricots, and it is then ready for enamelling. Working to the colored sketch, our Chi ese workman, with a small iron trowel packs the wire cells, or cloisons, with pig ments in paste form, until each cell is filled with its appointed color. Then he fires the work again, in the same way as before, this time for about ten minutes. When the vase is taken from the charcoal fire the pigments have shrunk into the wire cells and have acquired wonderful brilliancy. But bubbles have appeared to mar the surface. The workman takes the vessel in his lap, and patiently breaks every tiny bubble with a small hammer and a sharp-pointed nail, and fills the holes with more color.

The coloring and firing process is re peated until the pigment, after firing, is level with the top of the wirework. It may have to be dome as many as eight times on fine work, each time entailing the repairing process.

After the final firing the vessel is put on a lathe and polished, first with a file, then with sandstone, and finally with charcoal made from lime trees.

The finished vessel has a wonderfully brilliant surface upon which the wire pattern can be seen, clear and sharp, in the most beautiful tracery. The delicate coloring, which will last as long as the bronze itself, shows the touch of the real artist-craftsman.

The Japanese first invented the process upon metal, and the Chinese learned the art from them. However, the Chinese went one better; they found out how to to this day they are the only people who know how. Nobody else knows how to attach the copper strips to the pottery so that they will stand firing.

\section{Putting Infra-Red Rays to Work} (Continued from page 248)

experiments with carbon arcs in orde to increase the 'infra-red radiations. Special incandescent lamps have been studied and experimented with in seeking suitable illuminants for the small portable sets used in field work. These lamps are of the nitrogen- or neon-filled type in order to withstand a heavy current and give fonth an intense white light. The filaments, of extra large diameter, are made in the form of a helix, so as to concentrate the rays. A current of 6 to 8 volts is employed with such lamps.

The parabolic mirrors employed in the infra-red signalling system are made of gilded bronze or silvered glass. The foca length of these refiectors is approximately half the diameter, if an arc is employed but if an incandescent lamp is used the reflectors have an even more pronounced urve.

All the transmitting projectors are provided with quick-acting shutters which are used for chopping the rays so as to form the short and long fiashes of the receiver are provided with a sighting tube which lies parallel to the rays of invisible light, and aids in alining th stations for proper communication. Obviously, the two stations must always be witbin plain sight of each other, with no tervening obstructions.

Since the range of the transmitter is proportsonal to the diameter of the re flectors and the amount of light, all othe introduced various models and sizes of infra-red thansmitters. The small portinfra-red transmitters. The small port-
able transmitters, for work in the front 
line and accordingly intended for very as a result of the infra-red rays concenshort distances only, say not over two- trated on it and producing heat, is broken thirds of a mile, have a searchlight about up by a tikker or interrupter mechanism, 11 inches in diameter and operate with a similar to that employed in radio teleg 40- or 50-watt inctundescent lamp. A raphy for the reception of undamped storage battery supplies current for the incandescent lamp.

For greater distances, say one to two miles, the same projector is employed but with an arc lamp substituted for the incandescent lamp. For still longer distances, say from three to eight miles, the standard searchlights of the army and navy, measuring from 20 inches to 50 inches in diameter, are employed. The detector member is placed in front of the searchlight mirror for receiving purposes, so that the same searchlight is made to serve the dual function of transmitter
and receiver.

The receiving station of the infra-red ray telegraph consists of a parabolic reflector, at the foctal point of which is mounted a detector. In one system, known as the Charbonneau, the detection and reception of the infra-red ray signals is accomplished by visual means, while in the Herbert-Stevens and Larigaldie system the signals are detected by audible means.

In the visual or Charbonneau system of reception, a ribbon of paper coated with sulphur of zinc and giving forth a green phosphorescence is unrolled before a mirror. The light from a 10-volt lamp, specially filtered by means of a liquid color filter permitting only the luminous rays of high frequency to pass through, brillianitly illuminates that part of the ribbon on which it falls, and excites the phosphorescence. The infra-red waves, broken up into Morse signals at the transmitting end, are received by the mirror and concentrated on the paper ribbon, with the result that they become visible in the form of dark dots and dashes, since these rays tend to dim the phosphorescence. A special arrangement of the apparatus permits the visual means of de teotion to be emplcyed even in broad daylight.

The audible method of detection is of two general kinds: First, the direct audi ble detector, which, while simplicity itself, does not permit of amplification and hence limits the range of the infra-red transmitter; secondly, a thermoelectric arrangement which, while quite complicated, permits of mary stages of amplification and mits of mary stages of amplificati

The direct audible detector calls for a diminutive horn connected by flexible rubber tubing to a pair of ear pieces. This diminutive horn, a cross-sectional view of which appears in the accompanying line drawings, is placed at the focal point of a parabolic mirror. The horn is pro vided with a window or disk of quartz, facing the mirror, while the interior is heavily coated with lamp blarck which, as is well known, absorbs visible and invisible rays in a most efficient manner. The operation of this detector is simply thus: the infra-red rays pass through the window into the interior of the horn where they are absorbed by the lamp black. The heat of the waves serves to heat the air confined in the horn and rubber tubing, with the result that said air expands and contracts according to the varying degree of heat. This expansion and contraction affects the ear drums. In this manner the infra-red sig nals are made audible and can be read by the operator. Obviously, such a detector does not readily lend itself to amplification of signals in its present form although it has possibilities that may be worked out in the future. This detector works well for infra-red ray telephonythe telephone modiflcation of the system -and short distances have been covered with it.

The second method worked out by Messns. Herbert-Stevens and Larigaldie consists of an electric thermopile placed at the focal point of a parabolic reflector. The current produced by the thermopile,

good audibility.

The thermopile in this instance presents numerous serious problems. It has to be extremely sensitive yet instantly and variably responsive; that is to say, it must have practically no electrical inertia. One of the most efficient thermopiles for this purpose consists of a metal plate $0.01 \mathrm{~mm}$. thick which is sealed by autogenous fusion on the point of a crystal of great thermoelectric power. The thickness of the plate and the diameter the point of contact are as small as possible, so as to give an arrangement of ery small heat capacity. The best re sults have been obtained with platinum
and a crystal of tellurium. A glass cell is used to contain the two elements and is provided with a fluorite window. The themoelectric couple is connected to a valve amplifier in the manner shown in one of the accompanying line dra.wings, which is self-explanatory. A potentiometer is included in the circuit in order to eliminate any currents due to local conditions causing temperature variation of the unctions. The thermopile is mounted in bulb very much afiter the fashion of an electric lamp, and the air is exhausted. In this manner the heat is conservel. A bayonet socket arrangement for the base removing and replacing a unit with little trouble.
The Heavens in March, 1920 (Continued from page 252) above Orion in the west, and Canis Mino above Canis Major in the southwest.

\section{The Planet}

Mercury is an evening star till the 20 th, and a morning star afterwards. He is best visible at the beginning of the month, when he sets at $7: 15 \mathrm{P}$. M. Venus is still a morning star, rising about 5:10 A. $M$. in the middle of the month. Mars is approaching opposition, and rises at $10: 30$

Jupiter is in Cancer, and crosses the meridian about 9 P. $M$. in the middle of the month. Satum is in Leo, and "souths" at $11 \mathrm{P}$. M. on the same date. Uranus is a morning star, too near the sun to be oibservable. Neptune is in Oancer, and observable in the evenng.

The moon is full at $5 \mathrm{P}$. M. on the 4 th in her last quarter at $1 \mathrm{P}$. M. on the 12 th, quarter at 2 A. M. on the 27th. She is nearest the earth on the 24th, and far month she passes near Neptune and Jupiter on the 2nd, Saturn on the 4th, Mars on the 8th, Venus and Uranus on the 18th Mercury on the 20th, and Jupiter and Neptune once more on the 29th.

Jupiter and Neptune are in conjunction on the 29th, Neptune being $58 \mathrm{~min}$

utes of arc north of his great neighbor. This will afford an excellent chance for bservers with small telescopes to idenify the remotest of the planets.

Princeton Univensity Observatory, Feb 1920.

\section{What About the Old-Fashioned} Winter?

(Continued from page 253) coldest of all winters to the thind warm est-and back again to one that lies comfortably on the cold side of the median line. Consider the decade from characterized as ruling warm through out. And against this consider the period from 1885 to 1903 , in which there was but one winter that got appreciably below the grand average. All this forces us to conclude that the distribution of cold and warm winters has not changed new at $6 \mathrm{~A}$. M. on the 20 th, and in her first

leap between 1917 and 1919 , from the

\section{Lather is Doubly Effective When Shavaid is Used}

\section{As a free trial will convince}

Men the nation over have welcomed this new way to shave - this quicker, easier, pleasanter way. Shavaid. the new beard-softener, ends old, harsh treatments.

M EN who use Shavaid are finding that shaving isn't so difficult as it used to be. This new and scientific beardsoftener makes your daily shaving a pleasure. For it softens the beard instantly, soothes the skin.

No longer is it necessary to use hot towels nor to rub the lather in. Shavaid does away with all before-shaving preparations. Now you merely rub on a thin coat of Shavaid - then apply your favorite lather. (Shavaid is not a soap and does not lather.)

\section{Stop using hot towels}

Hot water applications before shaving can now be avoided. Hot water makes the face tender and it brings the blood to the surface at the wrong time.

Shavaid keeps the skin firm and smooth, the pores clean. You can shave closer without the usual abrasions. The razor does not pull. There is no scraping. Shavaid accomplishes instantly what old-time methods were thought to do.

You do not have to spend a lot of time rubbing the lather in. You do not need to rub the beard harshly with brush or fingers. Shavaid works better if the lather is merely spread over the face.

$\mid \begin{gathered}\text { At Druggists }-50 \mathrm{c} \text { a Tube } \\ \text { BAUER \& BLACK, Chicago, New York, Toronto }\end{gathered}$

\section{A delightful sensation}

The instant you apply Shavaid, note the cooling effect. Note that you can shave as closely as you like and there will be no drawn, burning sensation. Shavaid makes your face feel cool and comfortable.

The daily use of Shavaid keeps your skin smooth and firm, free from the tenderness and excessive dryness which are caused by hot water and rubbing in.

And best of all, when you use Shavaid, no aftershaving lotion is required. Shavaid is in itself a soothing emollient Its use keeps the cuticle firm, smooth and in healthy condition.

\section{Prove all this}

By mailing us the coupon below, we will send you at once a free trial tube of Shavaid. Thus you can find out for yourself the advantages of this easier, quicker, more comfortable way of shaving. You will join the thousands who would not do without it.

After you have proved to your own satisfaction that Shavaid is a real boon you can secure it from your druggist at $50 \mathrm{cc}$ a tube. Or, if he cannot supply you, we will be pleased to fill your order direct.

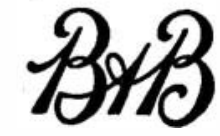




\section{The Biggest Cheese}

THE picture that goes with this story looks as though it might !be intended to represent the travels of a
ting gas-tank. As a matter of fact, however, insteal of being a case of the smallest in the world, this cylindrical affair is the largest thing of its sort ever madethe largest cheese, in fact. It was made to exhibit in counection with a recent dairy show at Chicago. It is 8 feet tall, 101/2 feet in diameter, and $\mathbf{3 3}$ feet around its circumference. It was manufactured in Appleton, Wis. and when packed for shipment to Chicago the entire hundle weighed 20 tons; the chese itself comprised 16 tons of this total. The milk to make this huge cheese was gathered from 1,800 farms, and it is estimated that 12,000 cows contributed to it.

Its combined size and weight made the transfer of the cheese to and from the cars quite a problem. Our picture shows it being unloaderl in Chicago, with the aid of nine huskies, a power-operated windlass, rollers, block and tackle, and a specially constructed inclined stage. Some statistical genius has figured that the cloth to wrap the big cheese cost $\$ 260$; and worse yet, that at the rate of one cheese sandwioh per day, the lucky purchaser of this dainty bit has enough eheese to last him till the sear $4 \pi 21$.

\section{The Trafic Tower}

VARIOUS schemes have been put forward in several of the more congested cities for safeguarding the traffic officer from the traffic which he is supposed to control. In the latest of these, now being tried out in New York, the additional advantage is secured of giving the a position from which he can get a much more comprehensive surver of the traffic streams bearing down upon his corner than has been possible.

Our photograph shows what the proposed traffic tower looks like. It is of much more ambitious character than the usual means proposed for raising the po. liceman above the general level of the street, as will be seen at a glance. In fact, it is frankly modeled after the railroad signal toner in more respects than ane.

These towers aro being tried out at two of New York's most desperately crowded corners-Fifth Avenue and 42nd Street, where the usual volume of traffic that will be found at the intersection of leading crosstown and up-and-down thoroughfares is vastly increased by the Fifth Avenue busses, by the proximity of the Grand Central Terminal, and by the fact that this district is at once one of hotels, of offices, and of great retail shops; and Fifth Avenue at 57th Street, the neck of the bottle for all the traffic that passes through Central Park, up and down town on Fifth Avenue, over the Queenshoro Bridge, and anywhere in New York via the motor busses, nearly all of which pass this corner or, worse yet, turn there. While of course no such elaborate system is contemplated as that of the railroad signal tower, with its interlocking block signals and the numerous sidings which are ordinarily controlled from the nearest block tower, the general scheme is to be one of signal lamps, as in the case of the rail road.

The signal tower should solve all the problems of the traffic officer save one. The mere cutting off of traffic on one of two intersecting streets, to allow traffic to pass through the other, will be much more effectively ared for this way than by an officer who is half concealed amid a maze of vehicles. But the real problem of the traffic cop is the sorting out of the vehicles that want to go straight ahead from those that desire to make the turn. Those turning to the right create no problem, unless there are two or more parallel lanes of traffic in egch direction and they try to turn out of one of the inner lanes and cut across the outer ones. But when it becomes necessary to take the long turn to the left on the intersecting street, the

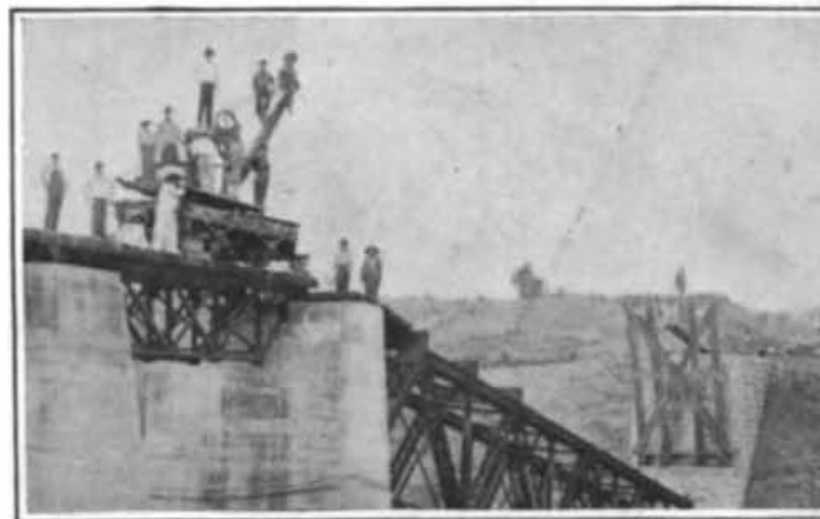

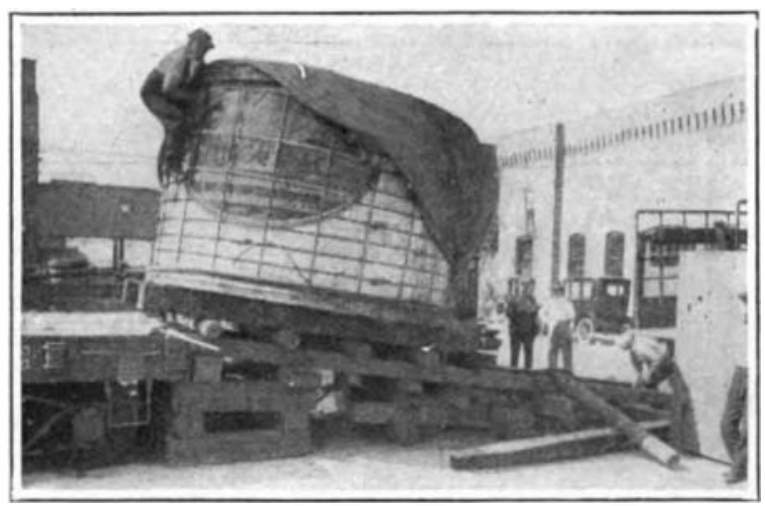

A 16-ton cheese beirig unloaded from the car on which it was shipped

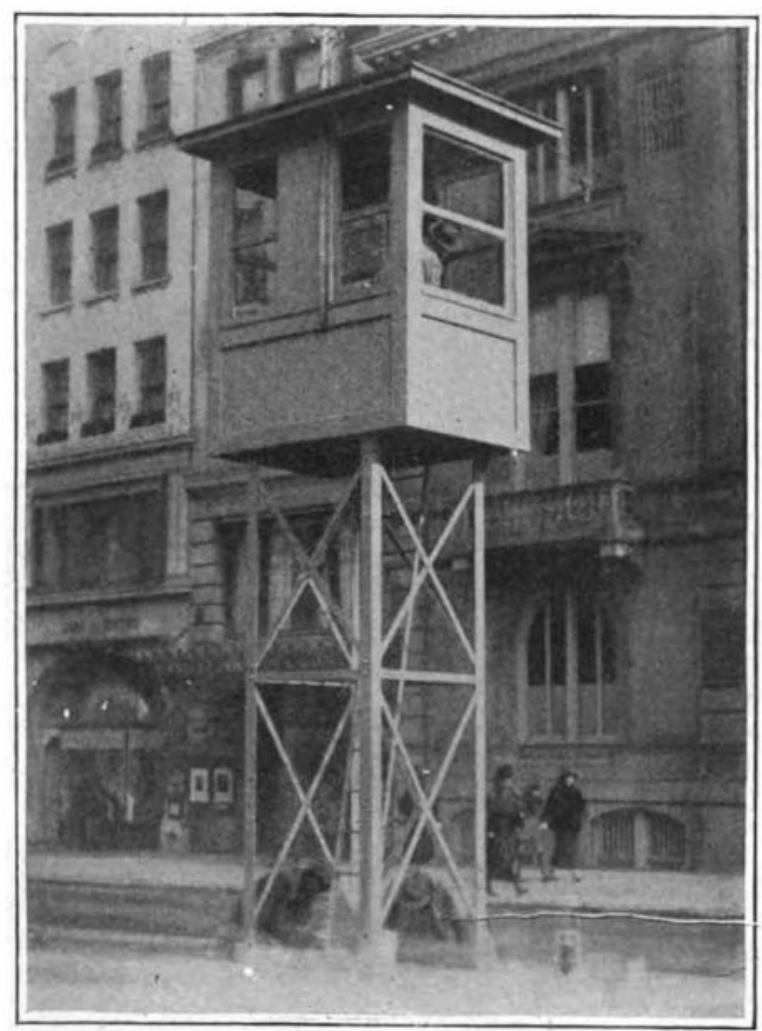

The fatest style in traffic towers, as now being tried in New York

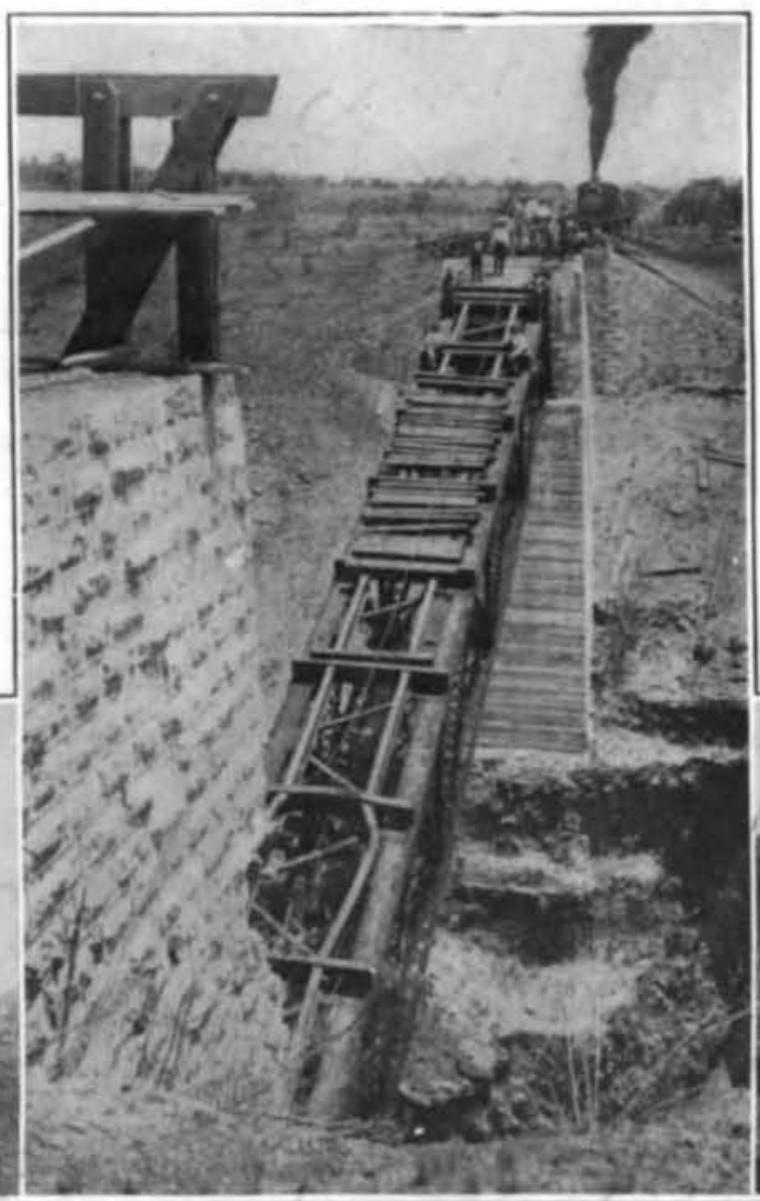

driver involved must cross the line of vehicles moving in the opuasite direction along the street out of which he is turning. The officer on the pavement can hold up individual cars affected by this incident long enough to allow the turning car to thread its way through the maze; the officer in a high tower has not this advantage. Whether all the other excellent features of the tower ivill be sufficient to overcome this will appear after trial An effort is to be made to overcome or at least to minimize the difficulties of the traffic signalman under this head by providing him with a third light in each dlrecton, in addition to the two which would be employed for "Stop" and "Go." This third signal, presumably, will cut off the traffic along the two intersectlog lines which must be crossed by the car making the long turn, while leaving open the lines out of which and into which he is turning. With proper coöperation on the part of the drivers, it would seem that this might work well; at any rate, it is decidedly worth a trial if there is any chance that it wovld make the traffic tower practicable.

\section{Restoring Mexico's Railroads}

SHOR'ILY after the beginning of the revolution $D$ against Huerta, in 1913, and for a long time subse quent thereto, the destruction of railroad tracks, bridges, stations, etc., became cammon practice in $\mathrm{Mez}$. ico in order to hamper the movernents of opposing forces. Some novel devices were employed in carrying out this destructive work, as set forth in these columns at that time. Tracks were destroyed and rebuilt over and over again, as the roads were captured and recaptured by different factions, and if destruc tion was rapid, so was restoration. The Mlexican railroad men showed themselves experts at this sort of work, and it was a constant matter of surprise to the foreign correspondents with the Constitutionalist Army (of whom the writer was one), to see how quickly traffic was restored upon lines which had been so thoroughly ruined that nothing but some bent and twisted rails and the right-of-way were left.

The work of reconstruction proceeded as rapidly as the different portions of the country were pacified by the present authorities, and now every road in the Republic is in operation with the exception of a few un important branch lines, while new lines have been built in several localities, bridges reconstructed, stations erected, and all this from the net earnings of the roads thenselves, without calling for a dollar of outside money.

The latest lines to be restored were in the State of Morelos, so long dominated by Zapata but entirely pacified during the past year by General Gonzales. The accompanying photographs inlustrate the manner in which a good-sized bridge that had been blown up by the Zapatistas on the line from Puebla to Cuatla, was restored to its former position, repaired and put in good order for traffic, and all by the use of simple appliances. As will be seen the abutment upon or against which one of the spans rested was partially dynamited and the end of the structure dropped into the ravine beneath. It is a testimony to the good character of the masonry of this abutment that no more of it was injured than is shown. As will be noted, a gallows frame of heavy timber was erected on the abutment from which the span had been dtslodged, and from this a steel cable was led to a pulley attached securely to the end of the fallen span. The caible led back to 8 derrick car anchored to the track at the oppasite end of the bridge and passed over another pulley on the end of the derrick boom. From this it was taken to the pilot of a pewerful engine and attached thereto. When everything was "all set," signals were given and the locomotive slowly and steadily raised the span to its original position on the face of the abutment. The men whs planned and carried out this feat are justly proud of their accomplishment.-By G.F. Weeks.

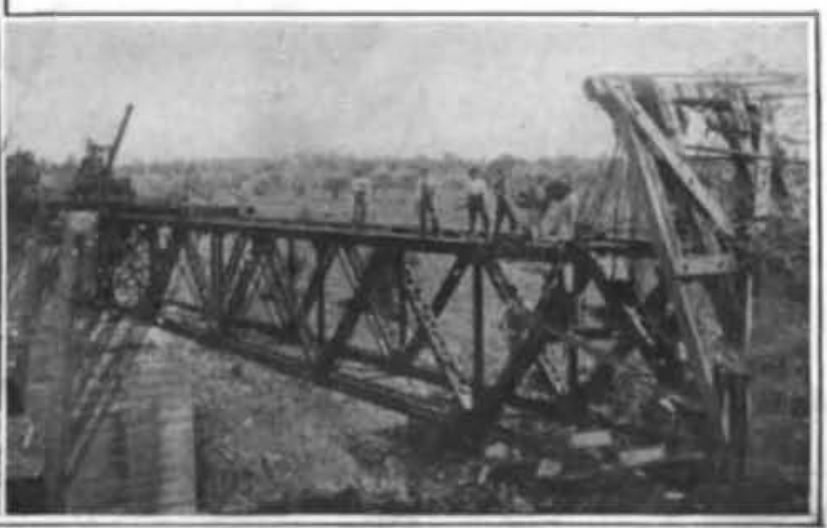

Three phases of the engineering work of restoring a Mexican railroad bridge dynamited by rebels 